\title{
A study of extracellular proteins produced by Aspergillus oryzae
}

\author{
Marwa R. Obiedallah ${ }^{\mathrm{a}, b^{*}}$, Mohamed B. Aboul-Nasr ${ }^{\mathrm{a}}$, Sabah S. Mohamed ${ }^{\mathrm{a}}$ \\ ${ }^{a}$ Botany and Microbiology Department, Faculty of Science, University of Sohag, 825244, Egypt \\ ${ }^{\mathrm{b}}$ School of Biological Sciences, University of Reading, RG2 6AJ, United Kingdom
}

Rec. 23 Aug, 2018 Accept. 26 Sept, 2018

\begin{abstract}
Extracellular secreted proteins by Aspergillus oryzae grew in yeast extract, malt extract, peptone and glucose (YMPG) were identified using mass spectrometry methods to determine reductase protein(s) in the fungal filtrate that might be responsible for reductase reactions, such as silver nanoparticles (SNPs) formation. FAD dependent oxidoreductase was one of the most prominent protein bands. This protein's structure is still unknown, so searching through the protein data bank (PDB) revealed that chain A, cyclohexylamine oxidase from Brevibacterium oxydans $\mathrm{IH}-$ $35 \mathrm{a}$ is the closet protein's structure to our identified protein. Our findings confirm that it in extracellular soluble protein that contains a flavin-adenine dinucleotide (FAD) legend which might be playing an essential role in reduction processes performed by that fungus extracellularly.
\end{abstract}

Keywords: Aspergillus oryzae; Bradford; extracellular proteins; MALDI-TOF.

\section{Introduction:}

Aspergillus oryzae (Ahlb.) Cohn belongs to the A. flavus group, section Flavi (Raper and Fennell, 1965), this section includes two main species, A. oryzae and A. parasiticus, of which most are known for potent aflatoxin producers. But, A. oryzae is considered as a nonpathogenic fungus (Domsch et al., 1980). None of the A. oryzae cultures has been reported for aflatoxin production (Yokotsuka et al., 1967; Manabe et al., 1968; Murakami, 1971; Kusumoto et al., 1990), so it was assumed that the aflatoxin gene homolog cluster is not functionally working in this species. Also, the US Food and Drug Administration categorize A. oryzae as 'generally recognized as safe' (MatsushitaMorita et al., 2010). It is a fast-growing fungus, with high extracellular enzymes activity and high competitiveness against other fungal species (Liang et al., 2009). all these advantages gave it the privilege to be widely in many industries, such as brewing.

Hence, little is known about its extracellular proteins and nanoparticles (SNPs) production by this fungus, it was selected for the experimental analysis of its extracellular secreted proteins, searching for reductant proteins that may contribute in reducing silver ions $\left(\mathrm{Ag}^{+}\right)$into silver nanoparticles (SNPs).

\section{Experimental:}

Aspergillus oryzae was isolated from Padina (brown algae) sample that was collected from the Sea Gull resort $35 \mathrm{~km}$ from El Gouna, Hurghada, Egypt. It was morphologically identified. Submerged culture (4 days) of A. Oryzae was prepared for large scale mycelium production in yeast extract, malt extract, peptone, glucose (YMPG) medium $(3 \mathrm{~g} / \mathrm{L}$ yeast extract, $3 \mathrm{~g} / \mathrm{L}$ malt extract, $5 \mathrm{~g} / \mathrm{L}$ peptone and $10 \mathrm{~g} / \mathrm{L}$ glucose. The washed mycelium $(0.1 \mathrm{~g} / \mathrm{mL})$ was suspended in Milli-Q water for $48 \mathrm{~h}$ at $25^{\circ} \mathrm{C}$ and $120 \mathrm{rpm}$. The mycelium was then removed by filtration using a sterile muslin cloth, and ammonium sulphate $\left(\left(\mathrm{NH}_{4}\right)_{2} \mathrm{SO}_{4}\right)$ was added to $100 \mathrm{~mL}$ this fungal filtrate in $\mathrm{H}_{2} \mathrm{O}$ to a concentration of $85 \%$ saturation. The solution was kept overnight at $4^{\circ} \mathrm{C}$ on a magnetic stirrer (Wingfield, 1998). 


\section{Precipitation of protein}

Using a sterile $50 \mathrm{~mL}$ Falcon tubes the solution was centrifuged at $12000 \times \mathrm{g}$ for 30 $\mathrm{min}$. The precipitate was dissolved in $2 \mathrm{~mL} 50$ $\mathrm{mM}$ acetate buffer ( $\mathrm{pH}$ 5.0) containing $1 \mathrm{mM}$ phenylmethylsulfonyl fluoride (PMSF) and (2 $\mu \mathrm{L} / \mathrm{mL})$ Halt $^{\mathrm{TM}}$ Protease Inhibitor Cocktail (100X), to avoid proteolytic degradation during protein extraction (Oda et al., 2006).

Desalting by dialysis

Snakeskin ${ }^{\circledR}$ Dialysis tubing (Product number 68035), 3,500 MWCO was soaked for $1 \mathrm{~h}$ in acetate buffer $(50 \mathrm{mM}$ sodium acetate trihydrate and $1 \mathrm{mM} \mathrm{PMSF} / 1 \mathrm{~L}, \mathrm{pH} 5.0$ ) before use. The $\left(\mathrm{NH}_{4}\right)_{2} \quad \mathrm{SO}_{4}$ precipitated proteins were then applied to the tubing and dialysis was performed overnight at $4^{\circ} \mathrm{C}$ on a stirrer against 1000 -fold excess of the same buffer (Oda et al., 2006).

Protein concentration and Bradford assay

Five $\mathrm{mL}$ of dialysed protein were transferred into a 2,000 MWCO Vivaspin ${ }^{\mathrm{TM}} 20 \mathrm{~mL}$ sample concentrators (Fisher Scientific) and centrifuged for $30 \mathrm{~min}$ at $4^{\circ} \mathrm{C}$ and $5,000 \times \mathrm{g}$. The protein concentration was estimated using a Bradford standard assay (Bradford, 1976).

Sodium-dodecyl-sulphate polyacrylamide gel electrophoresis (SDS-PAGE)

A vertical electrophoresis system which is a Mini-PROTEAN gel apparatus (Bio-Rad) was used to resolve the protein samples using sodium-dodecyl-sulphate polyacrylamide gel electrophoresis (SDS-PAGE) (LaemmLi, 1970). Samples $(40 \mu \mathrm{L})$ were mixed with 40 $\mu \mathrm{L}$ of $2 \mathrm{X}$ sample-loading buffer and boiled for $5 \mathrm{~min}$ at $95^{\circ} \mathrm{C}$. The tubes were centrifuged at high speed for 1 minute, then $10 \mu \mathrm{L}$ of each sample was loaded into the staking gel along with $10 \mu \mathrm{L}$ of the protein marker (PageRuler ${ }^{\mathrm{TM}}$ Broad Range Unstained Protein Ladder,Thermo Scientific, 5-250 kDa).

Proteins identification by tryptic peptide mass spectroscopy

The concentrated, precipitated extracellular proteins of A. oryzae were subjected to SDSPAGE and the resulting Coomassie blue stained protein bands were excised from the gel, diced into small pieces using a sterile scalpel under aseptic conditions, and were then placed into $0.5 \mathrm{~mL}$ microfuge tubes filled with sterile Milli-Q water. The (Gundry et al., 2009). protocol for protein sample preparation was then followed for further processing. A negative control (empty lane) and a positive control (protein marker) were also included.

Samples digestion (using Trypsin enzyme) and extraction

Porcine trypsin (Promega, UK) was resuspended in $10 \mathrm{mM}$ TEAB on ice. Then, 10 $\mu \mathrm{L}$ containing 50-200 ng of trypsin were added to re-swell the dehydrated gel pieces on ice and left for $20 \mathrm{~min}$. Depending on the amount of the gel for each sample, 30-50 $\mu \mathrm{L}$ of $10 \mathrm{mM}$ TEAB were added to fully cover the gel. Samples were left on ice for $5 \mathrm{~min}$, then incubated overnight at $25^{\circ} \mathrm{C}$ in the dark. Gel digestion was performed on dry ice for $5 \mathrm{~min}$, the gel slice was then allowed the gel to thaw and the contents were transferred to a fresh 0.2 $\mathrm{mL}$ PCR tube (Bioquote, UK). A total of 30 $\mu \mathrm{L}$ of $10 \% \mathrm{ACN} / 5 \%$ formic acid was added and the samples were sonicated (Jencons, UK) for 15 min. Addition of $10 \%$ ACN/5\% formic acid $(30 \mu \mathrm{L})$ was repeated and extracts were concentrated in a SpeedVacConcentrator. Thirty microliters of HPLC grade water (Rathburn, UK) were added to the samples, these were dried down, this was repeated and finally the dried samples were stored at $-20^{\circ} \mathrm{C}$ prior to analysis. Samples were analysed by mass spectrometer at the Chemical Analysis Facility (CAF), University of Reading.

\section{Results and discussion}

Extracellular proteins from two independent cultures (100 mL fungal filtrates) of $A$. oryzae were extracted and concentrated as previously mentioned. The standard curve represents the concentrations of BSA, using the equation $\mathrm{y}=$ $1397.5 x^{2}-282.55 x-3.6665$ (Fig. 1), protein concentration of the samples were calculated, where $\mathrm{x}$ is the mean of absorbance values at $595 \mathrm{~nm}$ and $\mathrm{y}$ represents protein concentration $(\mu \mathrm{g} / \mathrm{mL})$. were measured by Bradford assay ( 253.7 and $350.8 \mu \mathrm{g} / \mathrm{mL}$ ), followed by $\left(\mathrm{NH}_{4}\right)_{2}$ $\mathrm{SO}_{4}$ precipitation, and then dialysed (against acetate buffer $(50 \mathrm{mM}$ sodium acetate trihydrate and $1 \mathrm{mM} \mathrm{PMSF} / 1 \mathrm{~L}$ ), $\mathrm{pH}$ 5.0) and concentrated by ultrafiltration where the volume was reduced 5-fold from 5 to $1 \mathrm{~mL}$. Protein concentration was 2- and 3-fold 
increased from 456.7 and 596.3 to 912 and $1,790 \mu \mathrm{g} / \mathrm{mL}$.

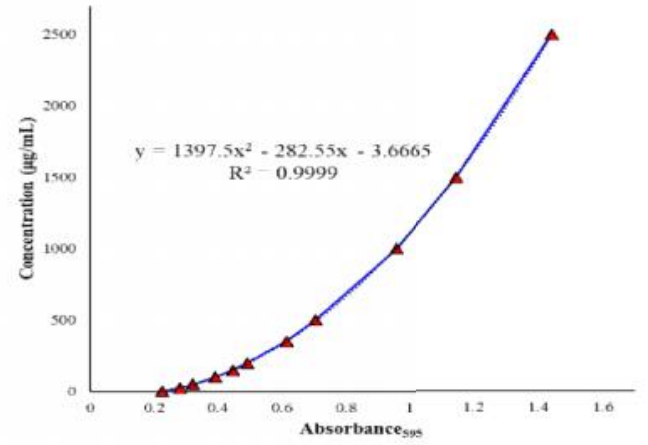

Figure 1:Standard curve of BSA concentrations vs Mean OD value. Standard curve was plotted using Microsoft Excel software.

Protein identification by mass spectrometry The SDS-PAGE of the extracellular protein sample indicated a series of distinct protein bands. The eight most prominent protein bands (along with a positive and negative control) were excised and subjected to identification by tryptic-digestion coupled mass-spectrometry. The ten identified samples were,band one for Trypsin gi|136429 as the negative control $(0.078 \mathrm{kDa}$, negative signal peptide), band two for DNA-directed RNA polymerase subunit beta gi|499207439 as the positive control $(150.935 \mathrm{kDa}$, negative signal peptide), band three for aminopeptidase 2 gi|169773399 (98.457 kDa, negative signal peptide), band four for glucan 1, 4-alphaglucosidase putative gi|238507489 (65.943 $\mathrm{kDa}$, positive signal peptide), band five for taka-amylase A precursor gi|217823 (55.395kDa, positive signal peptide), band six for FAD dependent oxidoreductase, gil169774077 $\quad(50.952 \mathrm{kDa}$, positive signal peptide), band seven for leucine aminopeptidase 1 gi|169782566 (41.308 kDa, positive signal peptide), band eight for FGGAP repeat protein, putative gi|238486310 (33.963 positive signal peptide), band nine for alkaline protease (oryzin) gi|217809 (28.980 $\mathrm{kDa}$, negative signal peptide) and band ten for unnamed protein product gi|83769688 16.300 $\mathrm{kDa}$, positive signal peptide).

From Mascot report, each GenInfo Identifier (gi) was used to search through NCBI website and full amino acid sequences were downloaded in .fasta* format for each protein. FASTA files were used to perform a search through SignalP 4.0 website and signal peptide for each protein has been determined (Petersen et al., 2011) (Fig. 3).Search parameters were set to eukaryotes as the organism group, Dcuttoff values, was set to default, graphics output was set to PNG, output format was set to standard and method was set to input sequences may include TM regions.
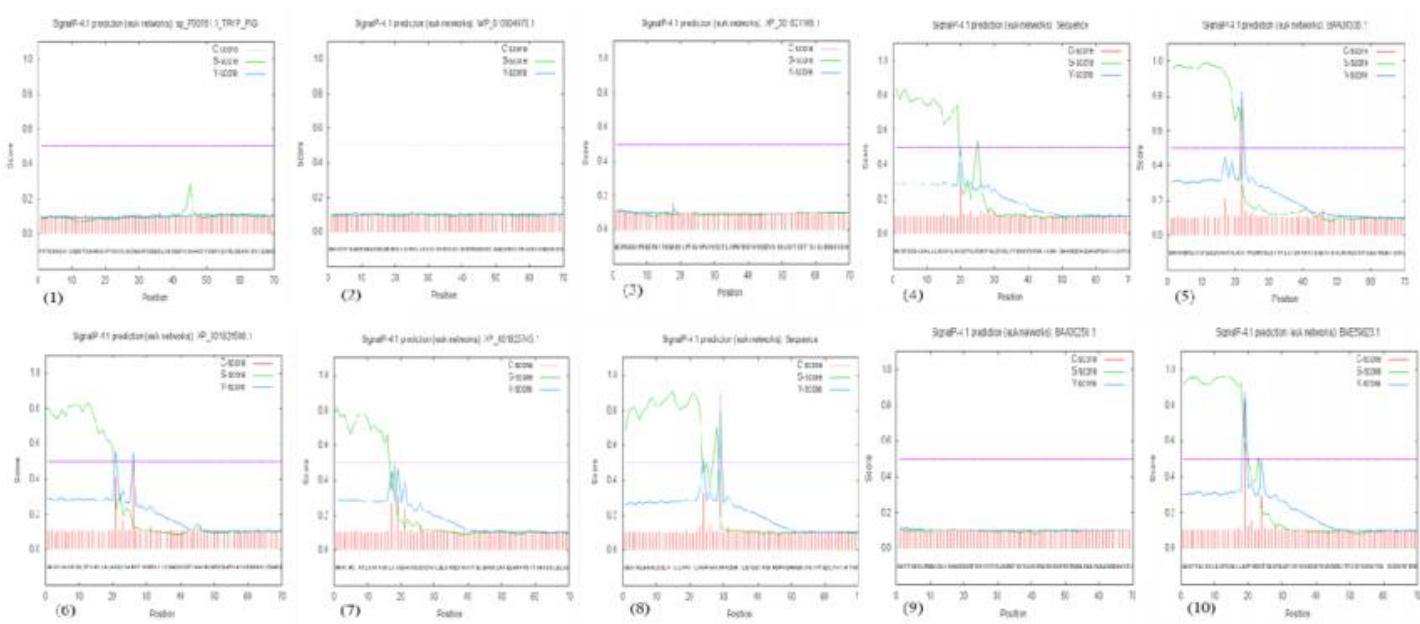

Figure 3: Signalof peptidesIdentified by MALDI-TOF.(1), Full Trypsin (negative control); (2),s'ubunit beta Escherichiacoli (positive control);(3), gi|169773399; (4), gi|238507489; (5), gi|217823; (6), gi|169774077; (7), gi|169782566;(8), gi|238486310; (9), gi|217809; (10), gi|83769688. 
Using the sequence of band number 6, the DeepLoc-1.0server could provide information about the subcellular localization of eukaryotics proteins using Neural Networks algorithm trained on Uniprot proteins with experimental evidence of subcellular localization (Fig. 4), showing that it is an extracellular soluble protein. This protein's structure (FAD dependent oxidoreductase gi|169774077 [Aspergillus oryzae RIB40]) is yet to be elucidated, so to define its structure a BLASTP was done through the NCBI website using data deposited from the protein data bank (PDB). It was found that the closest protein's structure to gi|169774077 is the chain A, cyclohexylamine oxidase from Brevibacteriumoxydans IH-35a (Mirza et al., 2013). (Fig. 5) with E-value: 3.75e-04, bit-score: 43.51, aligned-length: 48

and Identity to query: $48 \%$ (Fig. 6).

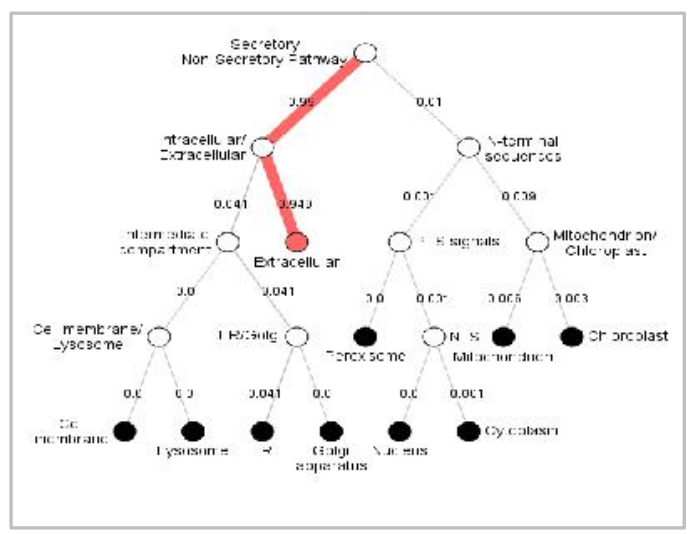

Figure 4: Hierarchical tree about band number six provided by DeepLoc-1.0 server.

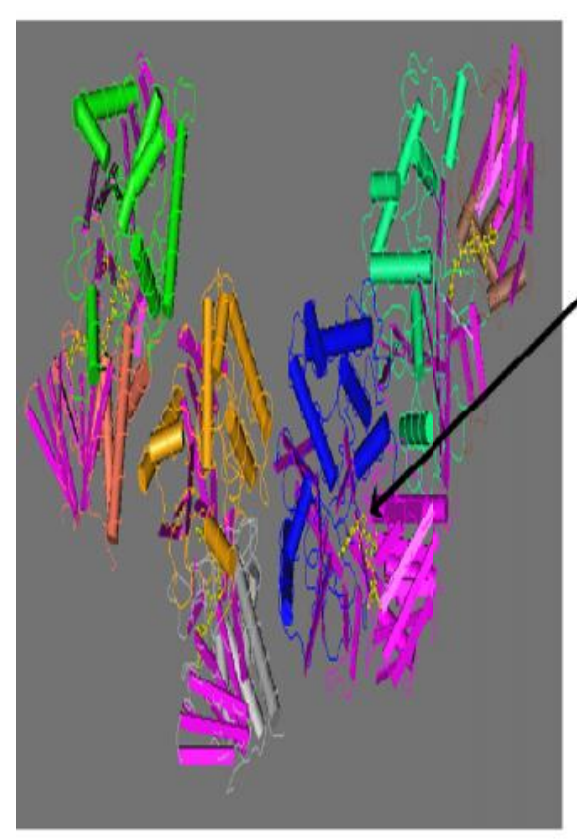

(a)

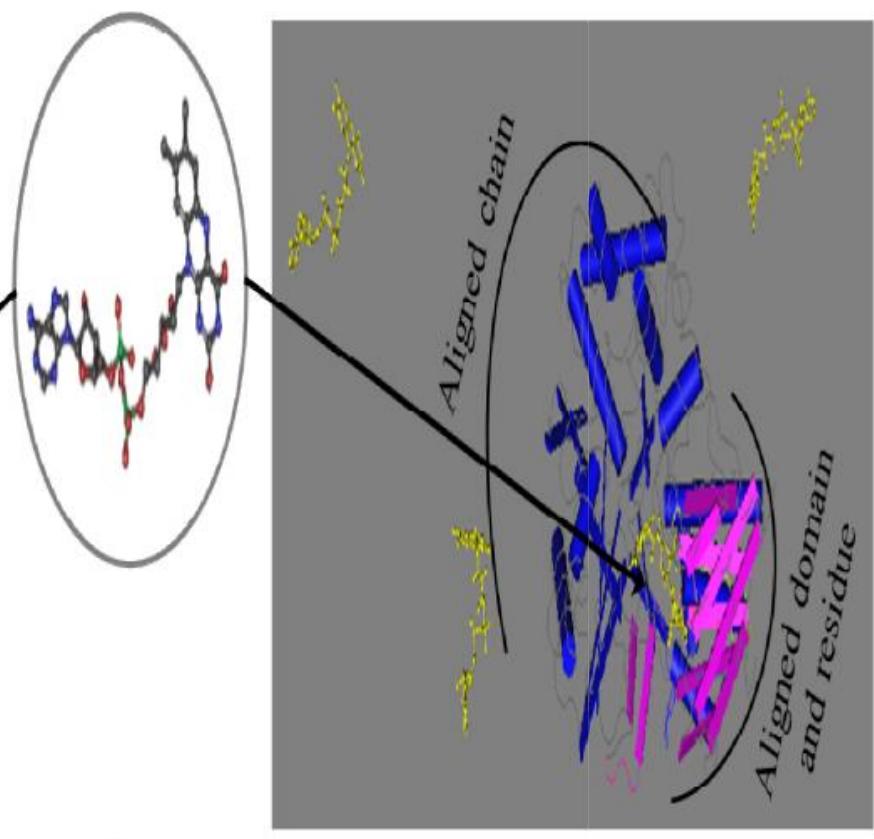

(b) (c)

Figure 6: Structure related to [gi|169774077|ref|XP_001821506|] generated by Cn3D software provided by NCBI. (a); 3D structure of Chain A, Cyclohexylamine Oxidase from BrevibacteriumOxydans Ih-35a; (b) Flavin-adenine dinucleotide (FAD), Formula: $\mathrm{C}_{27} \mathrm{H}_{33} \mathrm{~N}_{9} \mathrm{O}_{15} P_{2}$, MWt.: $786 \mathrm{Da}$, Putative function: Cofacto; (c) Aligned chain, domain and residue. 


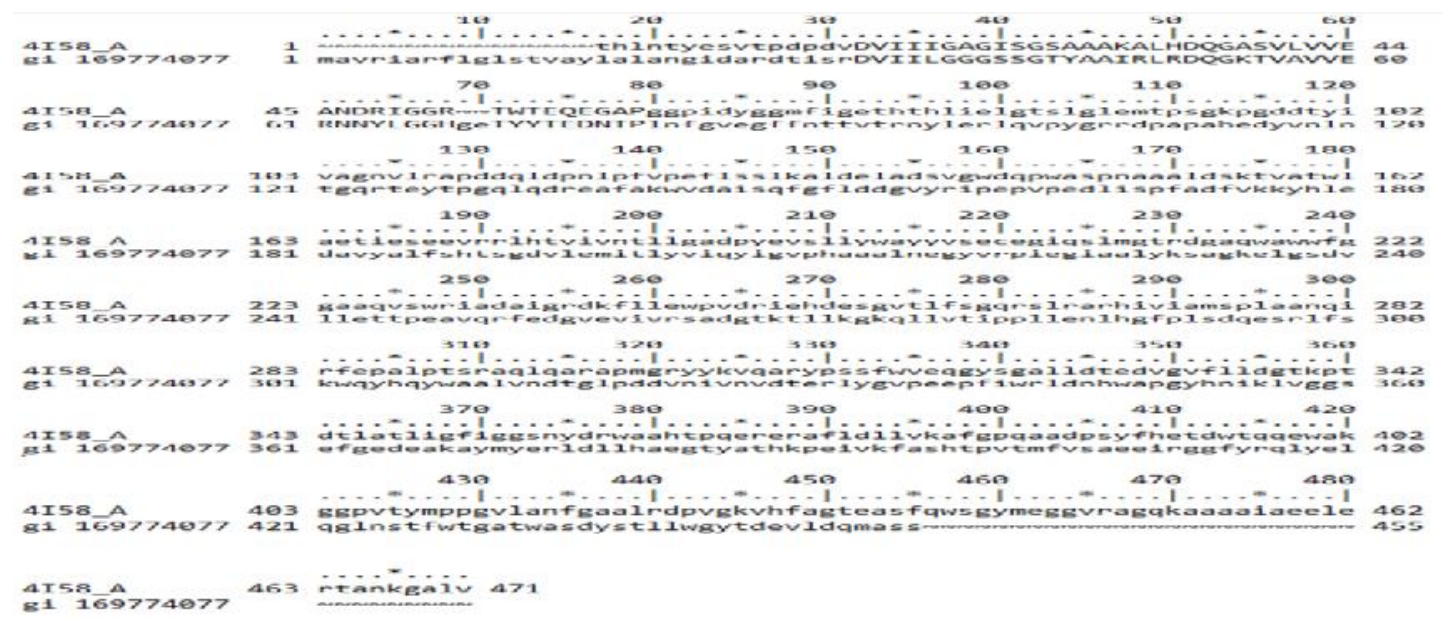

Figure 6: Alignment of gi|169774077 with chain A, cyclohexylamine oxidase from Brevibacterium oxydans IH-35a.

An interesting study about the extracellular protein profile of A. oryzae (Liang et al., 2009) reported that extracellular protein profile is always dependent on the type of nutrients found in the growth medium. Before that, (Bentley, 2006) also reported that fungal metabolites are always dependent on the medium used for the initial growth. According to this, it can be concluded that malt and yeast extracts, beside peptone that were used in the initial source of medium (YMPG) in this study were degraded by oryzin into polypeptides (Liang et al., 2009), then polypeptides can further be degraded into amino acids and dipeptides by leucine aminopeptidase (Liang et al., 2009). Thus, some of the produced amino acids would have reducing properties and help in reducing $\mathrm{Ag}^{+}$into $\mathrm{Ag}^{0}$. A study about SNPs production by A. oryzae, reported the presence of nitrate reductase in the fungal filtrate using a nitrate reductase assay (Phanjom \& Ahmed 2015), explain that it is implicated in SNPs synthesis, however the exact mechanism of this reaction still need to be fully addressed. Another two studies reported that NADH-dependant nitrate reductase plays an essential role in reducing $\mathrm{Ag}^{+}$into $\mathrm{Ag}^{0}$ in Fusariumoxysporum (Ahmad et al., 2003) and Bacillus licheniformis (Kalimuthu et al., 2008). Our results showed that, Band number 6 was identified as a FAD dependent oxidoreductase [Aspergillu soryzae RIB40] which is part of the family of proteins contains FAD dependent oxidoreductases and related proteins, thus the reduction activity of this fungal filtrate can be referred to the presence of this protein in its filtrate, while $\mathrm{NADH}$-dependant nitrate reductase was not identified among extracellular proteins found in the fungal filtrate in this study. Although, synthesis of various types of nanoparticles using filtrate of $A$. oryzae was previously reported (Phanjom \& Ahmed 2015); for silver nanoparticles (Bhimba et al., 2015); for gold nanoparticles (Binupriya et al., 2009), for iron nanoparticles (Raliya, 2013), but this is the first report linking its extracellular protein profile with SNPs generation and report the optimized conditions for SNPs synthesis using filtrates of this economically important species.

\section{Conclusions:}

In conclusion, among the eight identified extracellular proteins, one possesses reduction activity (FAD dependent oxidoreductase) which is mostly one of the proteins corporates to SNPs formation from $\mathrm{Ag}^{+}$. Our findings will have some important implications for using $A$. oryzae in metal nanoparticles formation by directing future researchers for investigating its proteinaceous components found in the fungal filtrate and exploring their function to 
present a deep understanding of the mechanism by which metal nanoparticles are formed by molecules found in the filtrate of this species.

\section{Acknowledgments:}

This research is financially supported by the Egyptian cultural affairs and missions sector, Egypt. Thanks to Prof. Simon Andrews for all Lab. facilities and guidance offered at the University of Reading, UK. Thanks to Dr. Peter Harris, University of Reading, UK for the EM-Lab facilities. Thanks to Micheal Nicholas staff at CAF laboratory for MALDITOF analysis.

\section{References:}

Ahmad, A., Mukherjee, P., Senapati, S., Mandal, D., Khan, M.I., Kumar, R., Sastry, M., Extracellular biosynthesis of silver nanoparticles using the fungus Fusariumoxysporum. Colloids and surfaces B: Biointerfaces. (2003). May 1; 28(4):313-8.

Bentley, R., From miso, sake and shoyu to cosmetics: a century of science for kojic acid. Natural product reports. (2006) ;23(6):1046-62.

Bhimba, B.V., Gurung, S., Nandhini, S.U., Silver nanoparticles synthesized from marine fungi Aspergillus oryzae. Int $\mathbf{J}$ Chem Tech Res. (2015) ; 7(01):68-72.

Binupriya, A.R., Sathishkumar, M., Yun, S.I., Myco-crystallization of silver ions to nanosized particles by live and dead cell filtrates of Aspergillus oryzae var. viridis and its bactericidal activity toward Staphylococcus aureus KCCM 12256. Ind. Eng. Chem. Res. (2009). Nov 20; 49(2):852-8.

Bradford, M.M., A rapid and sensitive method for the quantitation of microgram quantities of protein utilizing the principle of protein-dye binding. Analytical biochemistry. 1976 May 7;72(1-2):248-54.

Domsch, K.H., Gams, W., Anderson, T.H., Compendium of soil fungi. Volume 1. Academic Press (London) Ltd.; (1980).

Gundry, R.L., White, M.Y., Murray, C.I., Kane, L.A., Fu, Q., Stanley, B.A., Van
Eyk J.E., Preparation of proteins and peptides for mass spectrometry analysis in a bottom up proteomics workflow. Current protocols in molecular biology. (2009). Apr 1;90(1):10-25.

Kalimuthu, K., Babu, R.S., Venkataraman, D., Bilal, M., Gurunathan, S., Biosynthesis of silver nanocrystals by Bacilluslicheniformis. Colloids and Surfaces B: Biointerfaces. (2008). Aug $1 ; 65(1): 150-3$

Kusumoto, K., Goto, T., Manabe, M., Evaluation of activity for conversion of sterigmatocystin to aflatoxin in koji-molds. Report of National Food Research Institute (Japan). (1990) ; 54: 14-17.

Laemmli, U.K., Cleavage of structural proteins during the assembly of the head of bacteriophage T4. nature. (1970). Aug;227(5259):680.

Liang, Y., Pan, L., Lin, Y., Analysis of extracellular proteins of Aspergillus oryzae grown on soy sauce koji. Bioscience, biotechnology, and biochemistry. (2009). Jan 23;73(1):192-5.

Manabe, M., Matsuura, S., Nakano, M., Studies on the fluorescent compounds in fermented foods. Nippon ShokuhinKogyogakkaishi. (1968). Aug 15;15(8):341-6.

Matsushita Morita M., Furukawa I., Suzuki S., Yamagata, Y., Koide, Y., Ishida, H., Takeuchi, M., Kashiwagi, Y., Kusumoto, K.I., Characterization of recombinant prolyl aminopeptidase from Aspergillus oryzae. Journal of applied microbiology.

(2010) Jul;109(1):156-65.

Mirza, I.A., Burk, D.L., Xiong, B., Iwaki, H., Hasegawa, Y., Grosse, S., Lau, P.C., Berghuis, A.M., Structural analysis of a novel cyclohexylamine oxidase from Brevibacteriumoxydans IH-35A. PloS one. (2013). Mar 26;8(3):e60072.

Murakami, H., Classification of the koji mold. J. Gen. Appl. Microbiol. (1971); 17(4):281-309. 
Oda, K., Kakizono, D., Yamada, O., Iefuji, H., Akita, O., Iwashita, K., Proteomic analysis of extracellular proteins from Aspergillusoryzae grown under submerged and solid-state culture conditions. Applied and environmental microbiology. (2006). May 1; 72(5):3448-57.

Petersen, T.N., Brunak, S., von Heijne G., Nielsen, H., SignalP 4.0: discriminating signal peptides from transmembrane regions. Nature methods. (2011) Oct; 8(10):785. http://www.cbs.dtu.dk/services/Signal $\underline{P l}$.

Phanjom, P., Ahmed, G., Biosynthesis of silver nanoparticles by Aspergillus oryzae (MTCC No. 1846) and its characterizations. Nanoscience and Nanotechnology. (2015); 5(1):14-21.
Raliya, R., Rapid, Low-Cost, and Ecofriendly Approach for Iron Nanoparticle Synthesis Using Aspergillus oryzae TFR9. J Nanopart. (2013); 2013.

Raper, K.B., Fennell, D.I., The genus Aspergillus. William \& Wilkins Co., Baltimore. (1965).

Wingfield, P.T., Protein precipitation using ammonium sulfate. CurrProtoc Protein Sci. (1998); 13(1), A-3F.

Yokotsuka, T.M., Sasaki, T., Kikuchi, Y.A., Nobuhara, A., Studies on the compounds produced by moulds. Part I. Fluorescent compounds produced by Japanese industrial moulds. Nippon NougeikagakuKaishi. (1967); 41:3238.

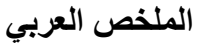

دراسة البروتينات التي ينم إفرازها خارجيا بواسطة فطر الأسبرجيلاس أوريزي الذي سبق تنميته علي وسط غذائي مكون

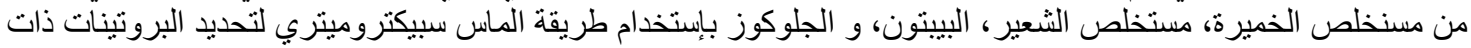

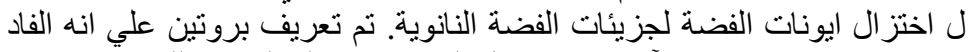

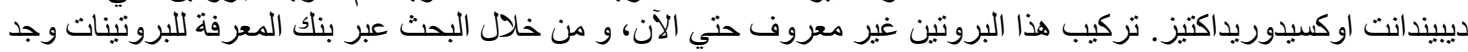

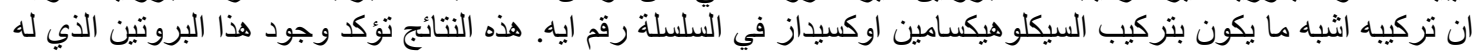

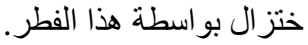

